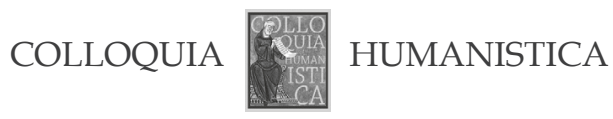

From the Editors

\title{
Who Gets Carried Away by Europe?
}

Tn July 2014, the Young Academies from Belgium, Denmark, Germany, the Netherlands, Poland, Scotland and Sweden announced an international contest. "Who gets carried away by Europe?" - was the prize question to which all the participants were asked to give a reply.

"Europe attracts and divides. It makes us dream, but it also has a reality with boundaries that shape our lives. What are the dynamics of integration? Whom does Europe sweep off their feet? Does European integration create community or does it lead to exclusion?" - announces the special website (http://www.aquestionforeurope.eu/) dedicated to the undertaking, which welcomed works in nine different languages.

Until the beginning of December 2014 - which was the deadline - more than 130 contributions were sent in. The entries could take every imaginable form. This made for a particularly difficult task for the jurors, who had to consider simultaneously scholarly works, short stories, non-fiction texts, dramas, poems, photographs, films, even broadcasts and pieces of music.

Six months later, during the Award Ceremony in Berlin, the first prize was presented to Christine Lehnen form Germany for the short story Zeus/ Europa. Krzysztof Usakiewicz from Poland was awarded the second prize. Below we present his report Not Just for Kicks, which describes a football project called the Etnoliga, which has been ongoing in Warsaw for several years. The third prize was given to Line Zachariasen and Lisa Staugaard from Sweden for a photo report from refugee centres in Sicily.

This is an Open Access article distributed under the terms of the Creative Commons Attribution 3.0 PL License (creativecommons.org/licenses/by/3.0/pl/), which permits redistribution, commercial and non-commercial, provided that the article is properly cited. (C) The Author(s), 2016

Publisher: Institute of Slavic Studies, Polish Academy of Sciences

Editor-in-chief: Jolanta Sujecka

Conception and academic editing of this issue: Jolanta Sujecka 